\title{
OXIDASES AND RELATED OXIDATION-REDUCTION SYSTEMS
}

$\mathrm{A}^{\mathrm{v}}$ $\mathrm{N}$ international symposium on oxidases and related oxidation-reduction systems was held at Amherst Colloge, Amherst, Massachusetts, during July 15-19. The organizers of tho symposium (T. E. King, H. S. Mason and M. Morrison) made use of the presence of many biochomists in the United States for the sixth Intornational Congress of Biochomistry, which was held in New York at the end of the month, to bring together most of the leading workers in tho field. Tho symposium was restricted to 49 participants, all of whom except two presented papers. Tho geographical distribution of the speakers was: United States, 28; Japan, 5; United Kingdom, 4; Swoden, 3; Australia, 2; Israel, 1 ; Switzerland, 1 ; Germany 1; The Netherlands, 1. The symposium was generously supported by grants from the National Institutes of Health and the Office of Naval Research. The organizers were assisted by an advisory committee consisting of B. Chance, P. George, M. D. Kamen and E. C. Slator.

The fir'st session of the symposium, on fundamental chemistry, was opened by P. George, who took as his theme the "Fitness of Oxygen" (ef. Lawrence J. Henderson's The Fitness of the Environment, first edition, Macmillan, New York, 1913; Beacon Paperback, Boston, 1958) as a terminal oxidant. N. Sutin discussed the mechanisms of some electron transfer reactions in solutions. F. W. Cope pioposed a new kinetic theory of eloctron and ion transport, based on electron conduction within semiconductivo particulate and membranous solid structures. His claim that the application of solid-state physics to enzyme kinetics is more fruitful than the conventional theories based on the 'law of mass action' was rather strongly attacked both by Sutin and by Chance. In general, it appoared that the biochemist is not ready to abandon the conventional approach for one that does not seem to offer any advantages, and which, according to B. Rosenberg's paper on some problems in the electrical conductivity of proteins, appears at present to have very limited experimental support.

The second session on peroxidase-oxidasos, model oxidases, and related systems was opened by a theoretical investigation of the structure of oxygen-motallic ion complexes by L. L. Ingraham. His molecular-orbital calculations supporting a $\mathrm{F}_{\theta^{3}}+\mathrm{O}_{2}-$ structure for oxyhæmoglobin were vigorously discussed, especially by Sutin and L. Orgel. Organic chemistry was now brought into the picture by R. O. C. Norman speaking on the mechanisms of aromatic hydroxylation and ring-opening reactions, and by W. S. Caughey on structure and medium effects on the ractions of iron(II) porphyrins with oxygen and carbon monoxide. M. E. Winfield presented a mechanism for the autoxidation of myoglobin and proposed the first of many mechanisms brought forward during the symposium on cytochrome oxidase. I. Yamazaka suggested a mechanism of the ruaction in which poroxidase acts as an oxidase. W. E. Knox described his experiments on the activation of tryptophan pyrrolase by reduction and by hæmatin.

The third sossion was dovoted to oxidases containing non-hæm iron or copper (with the exception of cytochrome $c$ oxidase). D. I. Crandall discussed molecular oxygenation by iron-activated oxygenases. O. Hayaishi confined his attontion to comparativo invostigations on pyrocatechase and metopyrocatechase, reserving the more general aspects of oxygenases for a brilliant exposition at the oponing session of the International Congress of Biochemistry later in the month. Investigations on copper oxidases were opened by Bo G. Malmström, who discussed the two forms of copper which ho has shown to bo presont in these oxidases by determination of the electron-spin resonance spectrum. E. Frieden roported on the catalytic activity of ceruloplasmin and its inhibition, and C. R. Dawson concluded the session, but not the discussion on copper, by his papor on the ruaction betweon copper and the apoonzyme of ascorbato oxidase.

The chemists had the first word in the fourth session on flavin-containing oxidases. P. Hemmerich discussed the chemistry of flavin-metal interaction, doaling in particular with metal-ligand charge transfer, and A. Ehrenborg, the nature of flavin-free radicals. The biochemists continued with discussions by T. P. Singer on the comparative biochemistry of succinate dehydrogenase, by $Y$. Ogura on the action of mechanism of several Havin enzymes, by V. Massey on D-amino-acid oxidase, by R. C. Bray on xanthine oxidase, and by P. Handler on several metalloflavoproteins. The controversy which has raged for several yoars on whether the iron atom in iron-containing flavoproteins undergoes oxidoreduction in the course of the enzymatic reaction was not settled, even after an extra evening sossion. H. Beinert produced new and convincing evidence that iron is concerned in the $g=1.94$ signal in the electron-spin resonance spectrum which appears on reduction of these flavoproteins. This does not, however, prove that the iron atom is reduced, since the signal probably involves another atom, possibly a sulphur. V. Massey made a plea that his data, which show that the rate of reduction of the iron atom, as measured chemically, is several orders of magnitudo slower than the overall reaction catalysed by the enzyme, should not be ignored.

M. D. Kamen opened the fifth session with a discussion on the status of the Rhodospirillum hremoprotein and other atypical hæmoproteins as bacterial oxidases. I. C. Gunsalus considered the generation of active oxygen for mixed function oxidation, doaling in particular with invostigations arising out of his discovery that this reaction is involved in the lactonization of camphor. Microsomal oxidases were discussed in four papers: by $\mathrm{Hj}$. Staudinger on the mechanism of microsomal hydroxylation, R. W. Estabrook on spectral and kinetic investigations of microsomal pigments involved in this reaction, R. Sato on the CO-binding hæmoprotein and NADPH-specific flavoprotein in liver microsomes and their roles in microsomal electron transfer, and H. S. Mason on the structure and oxidase function of liver microsomes.

A 'freo' afternoon was devoted to a discussion of the controversial question of the separate identity of cytochromo $a$ and $a_{3}$. Most workers in tho field appear now to accept the postulate of Koilin and Hartree, which they made in 1939 , that cytochrome $c$ oxidase contains two differently bound hæm a molecules, one of which combines with oxygen and respiratory inhibitors, while tho other does not. However, the so-called 'unitary' hypothesis is still supported by Onunuki and Wainio. Most workers assume that a single protein contains both types of hæm $a$ prosthetic groups (Siamese twins according to T. King)-a concept which can be formulated cytochrome $a a_{3}$. There is at present no compelling evidence in favour of two separate proteins-cytochromo $a$ and cytochrome $a_{3}$ although this cannot yet be excluded.

Ten papers on cytochromo $c$ oxidase wore presented in the next two sessions, by $\mathrm{K}$. Okunuki (presented by $\mathrm{S}$. Takemori) on the reaction with trinitrophenylated cytochrome $c$, Q. H. Gibson on the reaction with cytochrome $c$, 
H. Beinert on the function and disposition of the copper, W. W. Wainio on some anomalous reactions of the oxidase, M. Morrison on its components and their reactions, E. C. Slater on its composition and oxidation-reduction potential, T. E. King on a cytochrome c-cytochrome oxidase complex, L. Smith on the reaction of the oxidase with eytochrome $c, \mathrm{P}$. Nicholls on its mechanism and $\mathbf{E}$. $\mathrm{E}$. Jacobs on its reaction with high-potential electron donors. Comments from R. Lomberg and K. Okunuki, who wore unable to be present, were submitted by E. C. Slater and S. Takemori. There is now general agreement that copper forms part of tho enzyme, although its exact role remains to be determined. Q. H. Gibson agrees with B. F. van Gelder and E. C. Slater that equal amounts of the $a$ and $a_{3}$ components are present in active cytochrome $c$ oxidase. Gibson's discovery that cytochrome $c$ oxidase preparations contain non-reducible cytochrome $a_{3}$ explains the higher ratios of $a: a_{3}$ reported by M. Morrison. P. Handler brought forward tho coupling of sulphite oxidation with the cytochrome $c$ oxidase ruaction as ovidence in favour of an iron $-\mathrm{O}_{2}-$ radical as an intermediate in the enzymo reaction.

The last two sessions wero dovoted to oxidase systems and oxidative phosphorylation in intact mitochondria. A. W. Linnane reported on the induction by oxygen of the synthosis of mitochondria in anaerobically grown yeast cells. E. R. Redfoarn discussed the interaction of electron carriers in the mitochondrial $\mathrm{NADH}_{2}$ and succinate oxidase systems. Oxidative phosphorylation was dealt with in four papers. L. Ernster described a now mothod for investigating phosphorylation in the cytochrome $b-c$ region, D. E. Griffiths examined possible reaction mechanisms at the pyididine nucleotide lovel and P. D. Boyer suggested carboxyl activation as a possiblo common reaction in substrate-levol and oxidative phosphorylation, and in muscle contraction. Boyor stated that thero is now no clear evidonce for a rolo for phosphohistidine in oxidativo phosphorylation, and that all data can be rationalized in terms of the succinyl- $\mathrm{Co} A$ synthetase being responsible for the incorporation of inorganic phosphorus-32 into mitochondrial protein-bound phosphohistidine. C. L. Wadkins reported interesting work on the oligomycin-inhibited, dinitrophenol-stimulated interaction between the ADP-ATP exchange enzymo and cytochrome c. B. Chance roported data on tho reactionvelocity constants for electron transfer and transport reactions. He proposed that three types of reactions are involved in oxidative phosphorylation: (1) a rapid electron-transfer process, limited by tho speed with which an electron doparts from an iron atom and by the spoed of its travel through tho hæm-linked groups to the periphory of the protein; (2) an electron-transfer process which involves a thermal reaction in which the adjacent electron-bearing hæmatin becomes properly orientated; (3) a process involving the formation of high-energy irtermediates of the cytochromes.

The last two papers dealt with the mitochondrial morphology as revealed by the electron microscope, with particular reference to the structure with projecting subunits discovered by Fernardez-Moran. Those features of this structure which have been regarded as essertial have gradually undergone a change, summarized colloquially by the sequences 'knobs', 'knobs on sticks' and 'the tripartite knobs-sticks-base plate'. Thore was general agrooment that the morphological structure is not an artefact, but no agreement as to its physical significance. D. E. Green defonded his suggestion that the structure represented the 'elementary particlo' of olectron transport. E. Racker, in a paper with D. F. Parsons, B. Chance and othors, discussed the corrolations betwoen electron-transport activity, ATPaso and the morphology of tho submitochondrial particles, which led him and his colloagues to conclude that the projecting sub-units do not contribute an essontial component to the electron-transport chain. A possible correlation botwoen the sub-units and ATPase activity (coupling factor I) was suggested. Those attending the symposium were not disappointed in their expectations of a vigorous discussion, which was brought to a close by Racker's revelation that the 'knobs-sticks-baso plate' structuro shown by electron microscopy had boen painted, in appropriate colours, by a Finnish artist in tho 'thirties.

The papors presonted at the symposium are to bo published in due course. Since all but two of thom were circulated to participants several weeks before the symposium, only 10 minutes were allowed for each presentation, hence maximum time was made available for discussion. The time-table for the symposium was planned on the hopeful assumption that tho participants would have read the preprints (weighing $3.5 \mathrm{~kg}$ ) before the meeting. Although in this respoct most of the participants disappointed the organizers, the discussions were mostly lively, and there can havo been fow points in the field of oxidases which wore left undiscussed.

If I may be permitted to record what struck mo most about this symposium-and the identical thought was voiced by one of the most sonior and most distinguished of tho participants-it was tho number, breadth and depth of tho contributions mado to the discussions by $\mathrm{B}$. Chance, covering everything from theoretical chomistry, through physical chemistry, mechanism of enzyme action, oxidative phosphorylation to the morphology of mitochondria. It was a masterly performance, which contributed much to the high standard of tho discussions. E. C. Slater

\section{EDUCATIONAL AND SOCIAL FAILURE: SOME FURTHER OBSERVATIONS}

\section{By JOHN BRADLEY}

School of Education, University of Leicester

\begin{abstract}
$\mathrm{A}^{\mathrm{N}}$ earlier roport of mine $e^{t}$ gave an account of a new projection technique which had been used to provido evidence of the development of a concept of a family dominance hierarchy in children of school age.

The projection tost was given to primary school children of 8-11 years of both sexes and to a group of 1,600 secondary modern school boys and girls of $11-15$ years, and tho results showed that the mother is regarded as the salient member of the family in the earlier primary years but that she is increasingly displaced by the father, the process of displacement being complete for the majority of ehildren by the fourteenth year.
\end{abstract}

Groups of children committed to approved schools and a group of childron who had failed to make satisfactory acadomic and social progress in a grammar school gavo a significantly different pattern of test results.

It was shown that social and educational failure, which can be defined as an obvious deviation by the child from the social and educational standards acceptablo to those in whose caro he finds himself outside the home, have a similar ætiology and that both can bo understood only through a study of the family authority relationships and a consideration of the child's response to these relationships. It was further shown that these relationships 